International Journal of Biomathematics

Vol. 2, No. 4 (December 2009) 543-545

(C) World Scientific Publishing Company

\title{
AUTHOR INDEX (Volume 2)
}

Agarwal, M., see

Freedman, H. I.

Aidman, E. V., see

Ivancevic, V. G.

Arunachalam, V., see

Rangan, A.

Bai, J., Teng, Z. \& Jiang,

H., Global exponential

stability of

reaction-diffusion

time-varying delayed

cellular neural networks

with Dirichlet boundary conditions

Cao, H., see Jia, J.

Chandra, P., see Singh, S.

Chaudhuri, K. S., see

Das, T.

Chen, X., see Li, H.

Christova, D., see

Vassileva, S.

Cui, J.-A., see Dong, Z.

Cui, J.-A., see $\mathrm{Wu}, \mathrm{C}$.

Das, T., Mukherjee, R. N.

\& Chaudhuri, K. S.,

Capital theoretic analysis

of a Holling-Tanner-type

prey-predator fishery

with taxation as a

control instrument

Devi, S., see Freedman, H. I.

Dong, Z. \& Cui, J.-A., Dynamical model of vivax malaria intermittence attack in vivo

Duan, X., see Liu, C.

Fan, Y.-H., Wang, L.-L. \&

Wang, M.-X., Notes on

multiple bifurcations in a

delayed predator-prey

model with

$\mathbf{1}(2009) 107$
$\mathbf{1}(2009) 1$
$\mathbf{2}(2009) 119$
$\mathbf{3}(2009) 377$
$\mathbf{2}(2009) 229$
$\mathbf{2}(2009) 213$
$\mathbf{2}(2009) 151$
$\mathbf{2}(2009) 197$
$\mathbf{1}(2009) 29$
$\mathbf{4}(2009) 507$
$\mathbf{3}(2009) 311$
$\mathbf{4}(2009) 507$
$\mathbf{1}(2009) 463$
$\mathbf{2}(2009) 151$

nonmonotonic functional

response

2 (2009) 129

Feng, E., see Li, X.

Feng, G., see Wang, L.

Freedman, H. I., Agarwal, M. \& Devi, S., Analysis

of stability and

persistence in a

ratio-dependent

predator-prey resource

model

3 (2009) 321

2 (2009) 139

Gan, W. \& Lin, Z.,

Coexistence and

asymptotic periodicity in

a cooperating model

Gao, S., see Zhang, Y.

Garira, W., see

Magombedze, G.

Gojović, M. Ž., Liang, D. \& Wu, J., Structured influenza model for meta-population

Huo, D., see Jiang, Z.

Ivancevic, T. T., see

Ivancevic, V. G.

Ivancevic, V. G. \& Ivancevic, T. T., Macroand microscopic self-similarity in neuroand psycho-dynamics

Ivancevic, V. G., Aidman, E. V. \& Yen, L.,

Extending Feynman's formalisms for modeling human joint action coordination

Jia, J. \& Cao, H., Dynamic complexities of Holling type II functional response predator-prey system with digest delay and impulsive harvesting on the prey
1 (2009) 107

2 (2009) 167

3 (2009) 253

1 (2009) 69

4 (2009) 525

4 (2009) 483

3 (2009) 243

3 (2009) 243

2 (2009) 229
1 (2009) 1 
Jiang, H., see Bai, J.

Jiang, Z., Zhang, W. \&

Huo, D., Stability and

bifurcation analysis in a

delayed predator-prey

system

Kofane, T. C., see Tabi, C. B.

Li, C., see Pei, Y.

Li, H., Chen, X., Zhang, F., Ma, J. \& Xu, C.,

Expression profiles of the cell migration-associated genes during rat liver regeneration

Li, X., Qu, R. \& Feng, E., Stability and Hopf bifurcation of a delay differential system in microbial continuous culture

Liang, D., see Gojović, M. Ž.

Lin, Z., see Gan, W.

Liu, C., Zhang, Q., Zhang, X. \& Duan, X., Dynamical behavior in a harvested differential-algebraic prey-predator model

Liu, L., Global stability in a tuberculosis model incorporating two latent periods

Liu, Z., Lü, S. \& Zhong, S., Novel exponential stability conditions for a class of interval projection neural networks

Lü, S., see Liu, Z.

Luo, Z., Optimal control for a predator-prey system with age-dependent

Ma, J., see Li, H.

Magombedze, G., Garira, W. \& Mwenje, E., The role of dendritic cells and other immune mechanisms during human infection with Mycobacterium

Tuberculosis

Mohamadou, A., see Tabi, C. B.
3 (2009) 377

4 (2009) 483

4 (2009) 405

3 (2009) 363

2 (2009) 197

3 (2009) 321

4 (2009) 525

2 (2009) 167

4 (2009) 463

3 (2009) 357

3 (2009) 287

3 (2009) 287

1 (2009) 45

2 (2009) 197

1 (2009) 69

4 (2009) 405
Mukherjee, R. N., see Das, $\mathrm{T}$.

2 (2009) 151

Mwenje, E., see Magombedze, G.

1 (2009) 69

Nakata, Y., Permanence for the Lotka-Volterra cooperative system with several delays

3 (2009) 267

Naresh, R., Pandey, S. \& Shukla, J. B., Modeling the cumulative effect of ecological factors in the habitat on the spread of tuberculosis

Pandey, S., see Naresh, R.

Pei, Y., Yang, Y. \& Li, C., Bifurcation of a mutualistic system with variable coefficients and impulsive effects

$\mathrm{Qu}, \mathrm{R}$., see Li, X.

Rangan, A. \&

Arunachalam, V., A threshold model for cell survival

3 (2009) 339

3 (2009) 339

3 (2009) 363

3 (2009) 321

2 (2009) 119

Sanyal, D. C. \& Sarkar, B., A theoretical framework relating to exponentially frequency-dependent selection model in Pollak's sense

2 (2009) 179

Sarkar, B., see Sanyal, D. C.

2 (2009) 179

Sekiguchi, M., Permanence of some discrete epidemic models

Shukla, J. B., see Naresh, R.

4 (2009) 443

3 (2009) 339

Shukla, J. B., see Singh, S.

Singh, S., Shukla, J. B. \& Chandra, P., Mathematical modeling and analysis of the spread of carrier dependent infectious diseases: Effects of cumulative density of environmental factors

Sobh, A. M., Heat transfer in a slip flow of peristaltic transport of a magneto-newtonian fluid through a porous medium
2 (2009) 213

2 (2009) 213

3 (2009) 299 
Tabi, C. B., Mohamadou,

A. \& Kofane, T. C., Localized breather-like excitations in the helicoidal PeyrardBishop model of DNA

Teng, Z., see Bai, J.

Teng, Z., see Zhang, Y.

Todorova, D., see

Vassileva, S.

Tsekova, K., see

Vassileva, S.

Vassileva, S., Tsekova, K., Christova, D. \&

Todorova, D., Intelligent software analyzer design for parameters evaluation of ternary heavy metal ions removal by immobilized fungal biomass

Wang, L., Xu, R. \& Feng, G., Stability and hopf bifurcation of a predator-prey system with time delay and Holling type-II functional response

Wang, L.-L., see Fan, Y.-H.

Wang, M.-X., see Fan, Y.-H.

Wang, X.-Y., see Yang, J.-Y.

Wei, H. \& Zhang, W., Maximum likelihood estimation for simplex distribution nonlinear mixed models via an EM algorithm

1 (2009) 9

4 (2009) 405

3 (2009) 377

3 (2009) 253

1 (2009) 29

1 (2009) 29

1 (2009) 29

2 (2009) 139

2 (2009) 129

2 (2009) 129

1 (2009) 61

Wu, C. \& Cui, J.-A., Permanence for a delayed discrete

predator-prey model with

prey dispersal

3 (2009) 311

4 (2009) 525

Wu, J., see Ž. Gojović, M.

Xiao, Y., A semi-stochastic model for $H I V$

population dynamics

3 (2009) 391

1 (2009) 19

2 (2009) 197

2 (2009) 139

$\mathrm{Xu}, \mathrm{R}$. , see Wang, L.

Yang, J.-Y., Zhang, F.-Q. \& Wang, X.-Y., SIV epidemic models with age of infection

Yang, Y., see Pei, Y.

Yen, L., see Ivancevic, V. G.

Zhang, F., see Li, H.

Zhang, F.-Q., see Yang, J.-Y.

Zhang, Q., see Liu, C.

Zhang, W., see Jiang, Z.

Zhang, W., see Wei, H.

Zhang, X., see Liu, C.

Zhang, Y., Teng, Z. \& Gao, S., A new result on the periodic solutions for discrete periodic n-species competition models with delays

Zhong, S., see Liu, Z.

Zhou, F., Existence and global attractivity of a positive periodic solution for a non-autonomous predator-prey model under viral infection

Zou, W. \& Xie, J., An SI epidemic model with nonlinear infection rate and stage structure

1 (2009) 19
3 (2009) 253

3 (2009) 287

4 (2009) 419

1 (2009) 61

3 (2009) 363

1 (2009) 1

2 (2009) 197

1 (2009) 61

4 (2009) 463

4 (2009) 483

1 (2009) 9

4 (2009) 463 